\title{
肢端肥大症ノ一例, 並ビニ本邦文献ノ綜括的考察
}

\author{
京都府立醫科大学飯塚內科 \\ 研究科學生醫學士藤本久雄
}

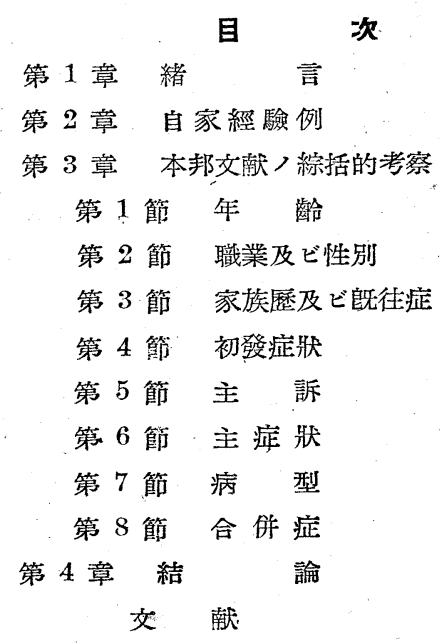

\section{第1章、緒言}

本症八既二幾百年前二於ヶル存在

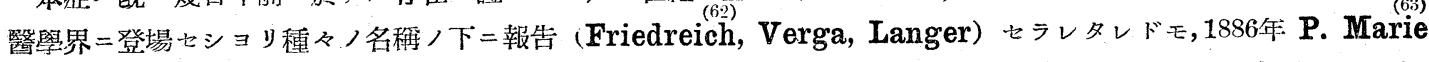

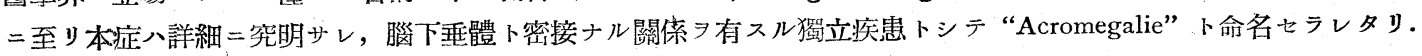

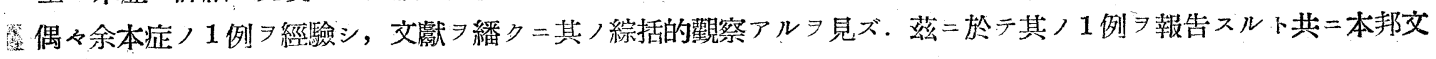

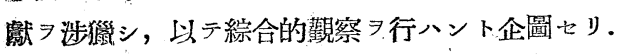

\section{第2章 自家經驗例}

虫 者西村某58歲男 織物業 昭和15年10月17日大院

主 挀 足ノ爸念感及ビ肢端肥大

家族屡・特記不可キモノナシ

㲘往症 30 歲まらり当

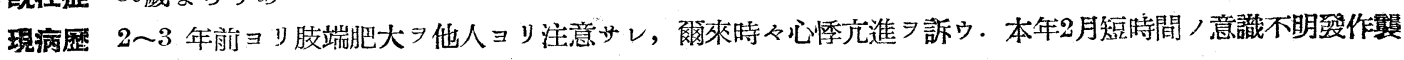

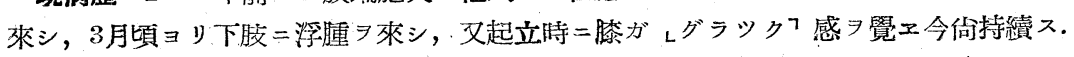

現 症 主要所見ノミフ述ブレバ, 體格大, 榮養良, 顏貌八本症特有ノモノニシテ顏面稍ふ浮腫狀. 肺左後上部呼 吸音粗, 左後下部呼吸音弱, 肝贜 4 橫指腫脹. 下肢感覺鈍麻，㙪手狀指趾，鎖骨突出著明.

\section{諸檢查成績}

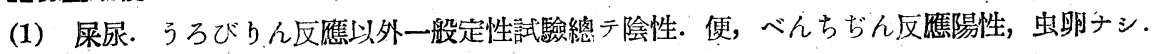

(2) 零. 結核菌陰性 (21/X 及ビ 14/XI). 


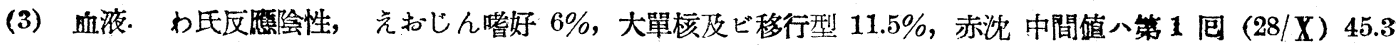
粍, 第2回 (6/X) 78.5籷, 乳酸凝固反磼 15分 (15/XI) Kochprob nach Kürten (-) (12/XI)

（4）糖. 2重負荷試驗デハStaubeffekt 陽性ナリ（23/X，30/X)

（5）胃液. 後液總酸度 82 度（胃酸過多）潜血反駡㓌性.

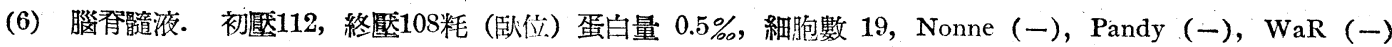

（7）基礎代謝. $0 \%$

(8) 藥效學的檢查. Pilocarpin 反應 (H), Adrenalin 反應 (HH)

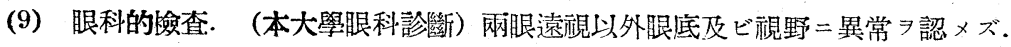

(10) 體測 (Martin 法)。身長 163.7粧, 體重 54.1䏕, Broca's Index 0.85 .

(11) X線檢查.

（イ）。肺所見，左肺上葉及ビ左肺門部腫湯，左陳舊性肋膜炎（6/XII 及ビ $27 /$ XII ).

（口）消化器 胃蠕動元進，爾側橫行結晹彎曲部下重.

（八）土耳古鞍 $\mathrm{be}=16.7, \mathrm{ce}=11.1, \mathrm{t}=170, \mathrm{~T}=170$, 骨破壞像及ビ破壞産物 7 認メズ.

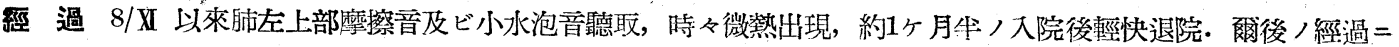

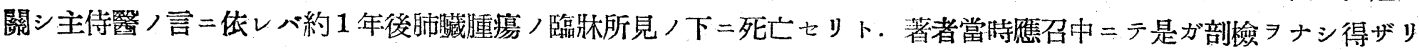
ショ甚ダ遺憾トス。

\section{第3章 本邦文獻 ノ綜括的考察}

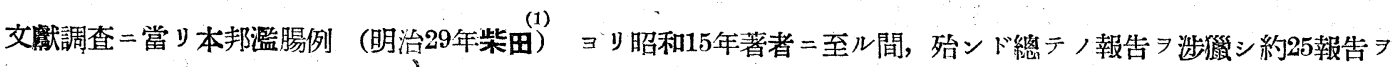

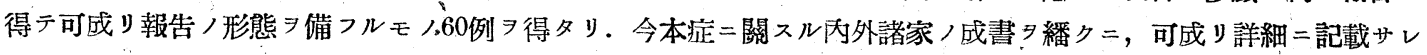

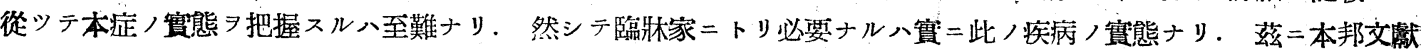
ノ總括的觀察 意義存ス（以下別表照）

\section{第 1 節 年 齢}

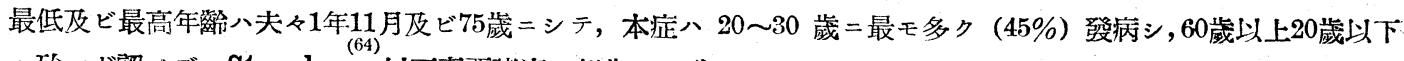
ニ八殆ンド認メズ. Sternberg 以下泰西諸家/ 報告ト一致ス。

\section{第 2 箕 職業及ビ性別}

農業皮ビ商業各11例，職人7例，贱部八種々雜多ナリ。男女ノ比八 $2: 1$ ニシテ Sternberg，報告ト異レソ。

\section{(4) 第 3 節 家族屡及ビ証往症}

明二遭傳的關倸アリト報告セル（中村） 1 例以外，祖母殊二母ノ體格大ナリシモノ，父ノ手足大ナリシモノ，兄ノ身 長大ナリシモノ，母系祖父母及ビ叔父體格大ナリシモノ，父系祖父肢端大りシモ/各1例アリ。斯クテ遺傳的關係八 認メ得ザルモ Borchardt ノ云ヘル如ク體質的素因 (Einzelne akromegaloide Züge) ノ證セラレルハ稀ナラザラン.

次二本病ノ誘因トシテ Schock, 外傷, 中毒, 傳染病等擧ゲラルルモ就中性病（殊=梅毒），既往八 $17 \%$ ノ成績 フ示シ, 現证トシテ $14 \%$ ノわ氏反㷳陽性者习認メリ.

Schock 及ビ外傷习誘因卜思惟セラレル症例モ少數存セリ。

\section{第 4 節 初 發症狀}

肢端肥大 37 例 $(62 \%)$ /多數 $\ni$ 占メ, 疼痛 25 例 $(42 \%)$, 視力障碍, 糖尿病症狀度ビ月經異常各 5 例 $(8 \%)$, 全 身僚念4例, 知覺異常3例, 其/他耳鳴, 赀眠及ビ失神發作各2例等ナリ.

\section{第 5 節 主挀}

百分率ノ大ナルモノョリ列擧スレバ疼痛 30 例 (50\%) 就中頭痛 22 例 $(37 \%)$, 肢端肥大 27 例 $(45 \%)$, 糖尿病 症狀 19 例 $(22 \%)$, 感覺異常 11 例 $(18 \%)$, 視力障碍 10 例 (17\%)，全身供念5例 $(8 \%)$ 等ナリ，其/他心悸穴

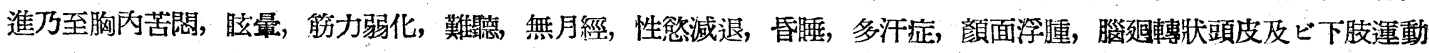
障碍等アリ。 


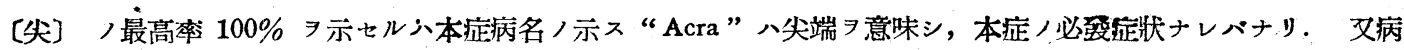
理解剖的主因八腦下垂體ニアレバ[鞍]，91\% ナル高率シ示セル八當然ナリ．眼症狀へ大部分專間的報告ニシテ其

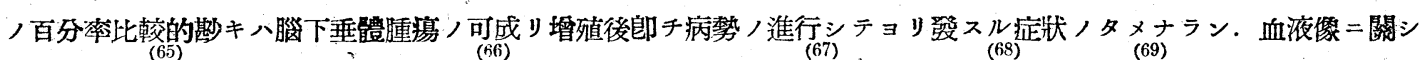

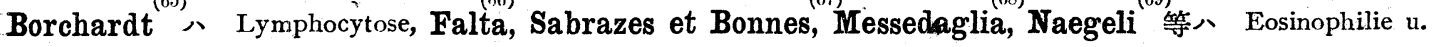
Monocytose 報告セル 對シ本邦報告习綜合スル = Eosinophilie 46\%, Lymphocytose $24 \%$, Monocytose $15 \%$ ， 出現率 シ示シ先ヅ內外諸家ノ意見ノ一致セル所ナリ．此ノ外本邦 ニテハ Neutrophilie $12 \%$, Anaemie $10 \%$ ノ成績 ヨ唯タリ.

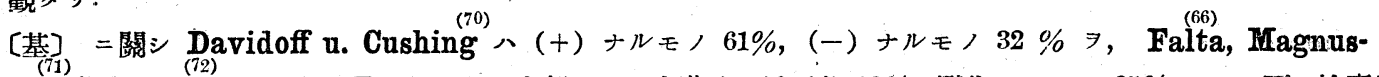
Levy, Salomon 、 $30 \%$ 上昇ヨ報ぜリ。本邦ニテハ光淮及ビ低下各 $38 \%$ ，變化ナキモノ $25 \%$ ニシテ而モ檢索例

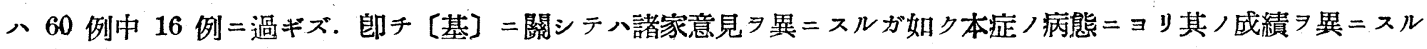
モノナランカ. 炭水化物代謝障碍 $=$ 就キテハ後述ス.

以上 12 症狀八何レモ $50 \%$ 以上/出現率 ルモノト信ズ．又是等主症狀中精神的並ビ二肉體的苦痛ノ大ナル八主訴トシテ出現ス可キモノニシテ, 換言スレバ第 5節主訴ノ出現率ノ大ナルモノ八第6節ノ條項ト合致ス可キモノニシテ, 兩節 照合スレバョク余ノ推理 裏付ケタル ヨ知ル．斯ル見地ヨリスルモ主訴及ビ主症狀ノ各條項八合理的ナルモノト思考ス。

\section{第 7 節 病型}

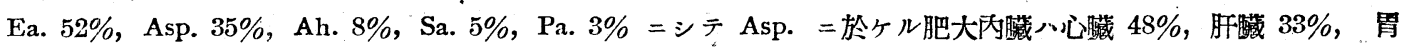

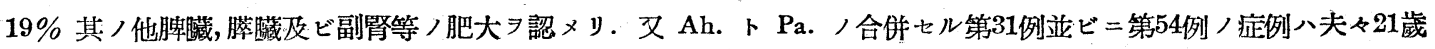
及ビ 25 歲ニシテ是八腦下垂體/機能克進が骨端接合線ノ未ダ化骨セザル前期ニ起レバE人症ヨ 化骨後ナレバ肢端肥 大症ヨ，更二其ノ中間期ナレバ肢端肥大症性巨人症ヨ起スト云フ肢端肥大症性巨人症/發生學說 セラレル。

\section{第 8 節 合 併 症}

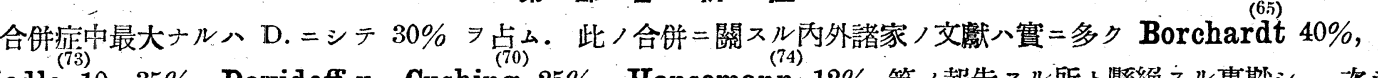

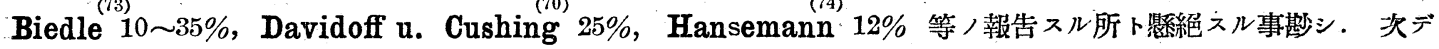
C. $15 \%$, E. $7 \%$ ，T. $5 \%$ ，A. $15 \%$ ，其／他特記六可キ併發症ナキモノ $35 \%$ ナリ.

\section{第4 章 結論}

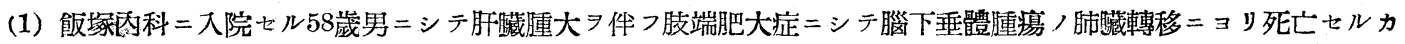
ト思惟セラルル1例 報告シ，併セテ本邦報告60例/綜括的觀察习試ミ本症ノ本邦二於ヶル實態ノ把握=努メリ。

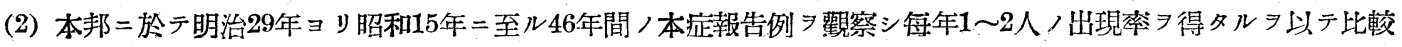
的稀有ナル疾患 $=$ 屬又.

(3) 男女ノ比八 $2: 1$ =シテ翇業及ビ商業/男二多シ.

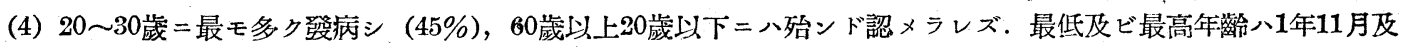
ビ75歲ナリキ。

(5) 初發症狀トシテ肢端肥大 $62 \%$ ニシテ最モ多ク, 次デ疼痛 $42 \%$ ニ認メラル。

(6) 遺傳的關係八殆ンド證シ難ク, 唯體質的素因/認メラレル八稀ナラズ.

（7）誘因トシテ擧ゲラル可キししょつくフ, 外傷, 中毒及ビ傳染病等ノ中前二者ト思惟ス可キ症例モ存セリ。傳染 病中性病入 $14 \%$ =及ブ よわ氏? 反㷳陽性率习認メリ。

（8）主訴トシテ疼痛, 就中頭痛 $(27 \%)$; 肢端肥大 ; 糖尿病症狀 ; 感覺異常 ; 視力障碍等ニシテ是等へ夫々 $50 \%$, $45 \%, 22 \% ， 18 \%$ 及ビ $17 \%$ ノ割合=認メラル。

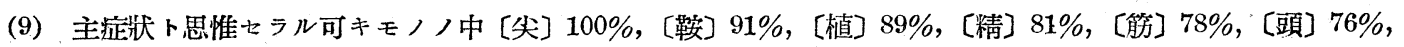
〔血〕 $71 \%$, [性〕 $67 \%$, [眼〕 $65 \%$, [腺〕 $65 \%$, [基〕 $63 \%$, [糖〕 $54 \%$. 〔腺〕中甲狀腺腫 $23 \%$, 副腎腫 $11 \%$ ，上

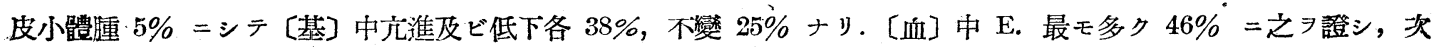


デ L. $24 \%$, M. $15 \%$, N. $12 \%$, A. $10 \%$ ナリ.

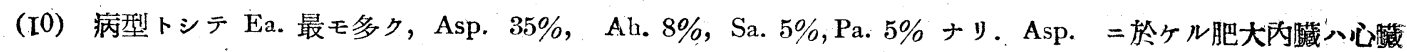

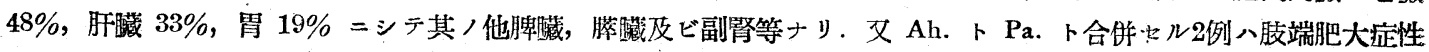
巨人症ノ成因

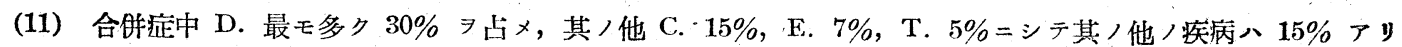
就中 D. ノ合併八泰西ノ夫レト殆ンド懸絕セズ。

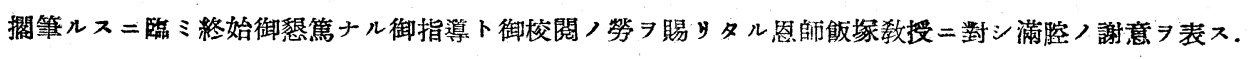

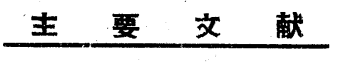

\begin{tabular}{|c|c|c|c|c|}
\hline . & 柴 & 田 & & 凉 醫 \\
\hline 2. & 長 & 尾 & & 露 \\
\hline $3:$ & 伊 & 藤 & & 第六回日本内分泌學會詰 \\
\hline 4. & 中 & 村 & & 京 都 醫 學 雜 詰 \\
\hline 5. & $\lambda$ & 瀑, 蓼 & 沼 & 近 \\
\hline 6. & 禺 & 園 & & 簬 \\
\hline 7. & 网 & 部 & & 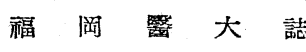 \\
\hline 8. & 渡 & 邊 & & 洙 醫 \\
\hline 9. & 榎 & 田 & & 事 新 \\
\hline 0. & 塚 & 原 & & 日本內科學會詰 \\
\hline 1. & 長 & 興 & & 斨 \\
\hline 12. & 䅬 & 田 & & 醫事 \\
\hline 13. & 谷村, & , 見浪, & 井上 & 東 京 醫 會 \\
\hline 14. & 山 & 中, & 位 & 臺 灣 醫 學 會 \\
\hline 15. & 井 & 上 & & 大 亚 衅 學 會 誌 \\
\hline 16. & 八 & 木 & & 含敷中央病院年報 \\
\hline 17. & 碓 & 居 & & 實： 驗＼cjkstart醫 \\
\hline 18. & 井 & 口 & & 日本之，醫 \\
\hline $19-22$ & 勝 & 木 & & 日本内分泌學會誌 \\
\hline 23. & 熊 & 谷 & & 實 \\
\hline 24. & 平 & \# & & 診 斷 $を \quad$ 治 \\
\hline $25-26$ & 谷 & 村, & \# & 東京醫事 新、誌 \\
\hline $27-29$ & 㗬 & 野 & & 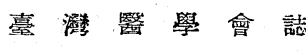 \\
\hline 30. & 畒 & 林 & & 日 本 内 學 會 \\
\hline 31. & 䎟 & 田 & & 同 \\
\hline 32. & 同 & 島 & & 眼 科，臨 牀 醫 報 \\
\hline 33. & 碓 & 居 & & 日本醫科大學詰 \\
\hline 34. & 植 & 田 & & 海軍 及 醫 會 詰 \\
\hline 35. & 度 & 澤 & & 日本内科 學會誌 \\
\hline 36. & 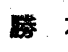 & 木 & & 日本內分泌學會 \\
\hline 37 . & 机 & 尾 & . & 賽 \\
\hline 38. & 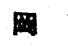 & 田 & & 臨 \\
\hline
\end{tabular}

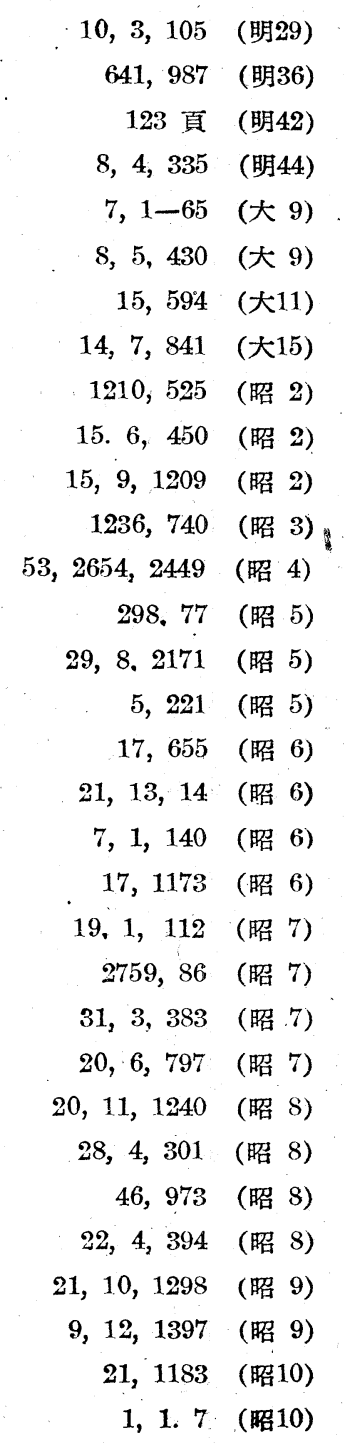




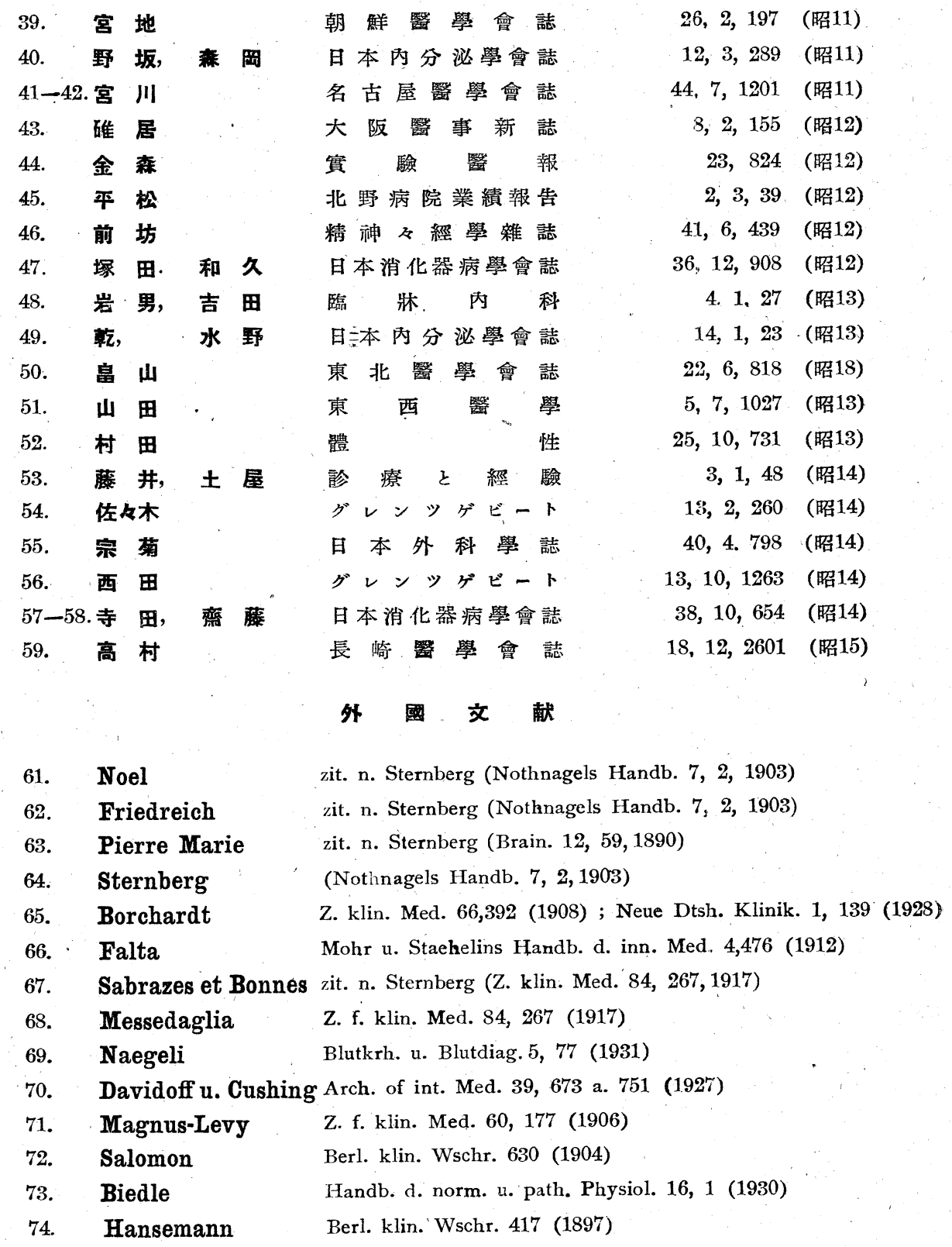


肢端肥大症二關 スル本邦報告例，綜括的㽞察 (1)

\begin{tabular}{|c|c|c|c|c|c|c|c|c|c|c|c|c|c|c|c|c|c|c|c|c|}
\hline \multirow{2}{*}{$\begin{array}{ll}\text { 番 } & \text { 年 } \\
\text { 號 }\end{array}$} & \multirow{2}{*}{ 性 } & \multirow{2}{*}{ 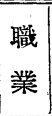 } & \multirow{2}{*}{ 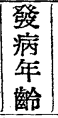 } & \multirow{2}{*}{ 初 發症 爿 } & & & & \multicolumn{5}{|c|}{ 䳛 } & \multirow{2}{*}{$\mid \begin{array}{l}0 \\
氏 \\
\mathbb{E} \\
\text { 應 } \\
\end{array}$} & \multirow{2}{*}{\begin{tabular}{|l|} 
拿 \\
症 \\
\end{tabular}} & \multirow{2}{*}{$\begin{array}{l}\text { 病 } \\
\text { 型 }\end{array}$} \\
\hline & & & & & & 尖 & 筋 & 鞍 & 頭 & 眼 & 性 & 腺 & 血 & 基 & 糖 & 植 & 精 & & & \\
\hline 3 & 우 & - & 1 & 視. & & & & & & + & & & & & + & & & & A. & Ast \\
\hline 42 & 우 & - & 25 & 頭. & 昏睡. & 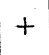 & & & + & + & + & & E. & & & & & & - & \\
\hline 56 & o & - & 48 & & 頭. 痛. & + & + & & + & + & + & + & A. & & - & + & - & & $\mathbf{T}$ & Asp \\
\hline 48 & $\hat{\delta}$ & & 18 & 肥. 糖. 視. & 痛 & + & + & + & - & + & + & + & & & + & + & + & & D. & Ah \\
\hline 29 & ㅇ & - & 29 & & 痛. 韋馨變調 & + & & \pm & + & + & + & + & - & & + & + & -1 & & A. & $\mathrm{Sa}$ \\
\hline 30 & $\hat{o}$ & 農 & 15 & & 頭. 痛. 除菱. & + & + & & + & - & + & - & E. & & + & + & & & D. & $\mathrm{Ea}$ \\
\hline 79 & q & - & 23 & 頭. 耳. 嗜眠. & 視. 頭. 肥. & + & + & + & + & + & + & + & & & + & + & + & +8 & DA & $\mathbf{E a}$ \\
\hline 46 & $q$ & - & 4 & 糖. 頭. 胘量. & 肥. 糖. & + & & + & + & & + & & - & & + & + & & & ED & $\mathrm{Ea}$ \\
\hline 942 & $\hat{\delta}$ & 農 & 21 & 肥. & 頭. 知.多汗. 筋 & + & + & + & + & - & - & & - & \pm & + & + & & & EI & Ea \\
\hline 051 & 우 & - & 3 & 肥. 月. & & + & + & + & + & + & + & & & & - & + & & & A. & $\mathrm{Ea}$ \\
\hline 54 & 우 & - & 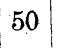 & & 視. 腦神經麻㾇 & + & & + & + & + & & & & & + & & & -1 & - & Ea \\
\hline 234 & $\hat{o}$ & & 3 & 頭. 瞱 & 視. 知. 多汗. & + & + & + & + & + & - & - & - & - & + & + & & & $1-$ & Ea \\
\hline 1343 & $\hat{\delta}$ & 職 & 25 & 肥. & & + & + & + & + & : & + & - & L.E & & - & + & + & - & C & $\mathrm{E}_{\mathbf{a}}$ \\
\hline 50 & q & - & 35 & 月. 知. & 肥. 頭 . 心悸穴進 & + & + & + & + & - & + & + & $\mathrm{L}$, & & - & + & - & - & $1-$ & As \\
\hline 42 & $\hat{o}$ & 職 & 22 & 頭. 肥. & 記憶力減退. & + & . & + & + & - & + & & $A E L$ & & - & + & + & - & C. & $\mathrm{Ea}$ \\
\hline 47 & $\hat{o}$ & 農 & 22 & & 痛. 性慾減退 & + & & + & & + & + & & E. & & 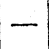 & + & - & - & . & As \\
\hline 75 & $\hat{o}$ & 職 & 72 & 頭. 部 & 頭. 痛. & + & & + & + & - & & & - & + & - & + & 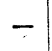 & & $\therefore$ & \\
\hline 47 & $\hat{\delta}$ & & 35 & 頭. & 頭. 肥. C. & + & + & + & + & - & + & - & E. & & $1-$ & & & & C. & \\
\hline 35 & 9 & 商 & 24 & & & + & & + & + & + & + & - & & & - & + & - & - & - & $\mathrm{Sa}$ \\
\hline 41 & $\hat{o}$ & " & 18 & 頭 & 頭. 心悸允進. & + & + & + & + & + & - & - & AN & - & - & + & 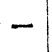 & - & - & \\
\hline 29 & $\hat{\delta}$ & 職 & 22 & 瓶 & 頭. 肥. & + & & + & + & + & - & - & $\mathrm{NE}$ & & - & + & 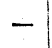 & - & & \\
\hline 34 & $f$ & 農 & 3 & & 頭. 槗. 俻. & + & & + & + & - & + & - & EL & + & + & +1 & - & - & D. & \\
\hline 41 & $\widehat{o}$ & 商 & 36 & 糖. & ·視.痛. 陰菱 & + & + & + & & + & + & - & - & & + & + & & + & $\mathrm{CD}$ & \\
\hline 26 & $q$ & - & 20 & 頭. 肥. 失神. 脫力 & 頭. 隐. & + & + & + & + & + & + & & E. & - & - & - & + & - & - & \\
\hline 29 & $\hat{o}$ & 農 & 21 & 肥. & 肥. 隐. 心悸穴進 & + & + & - & & & & & & & & + & + & - & C. & \\
\hline 24 & $\hat{o}$ & 商 & 19 & & 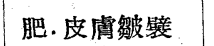 & + & & - & & & & & & & & + & & - & C. & \\
\hline 40 & $\delta$ & 小 & 38 & 頭. & 頭. 痛. 肥. 脫力 & + & + & + & + & + & - & - & $\mathrm{ME}$ & & - & + & + & - & A. & \\
\hline 43 & 0 & 商 & 10 & & & + & - & + & - & - & - & - & & & - & - & - & - & - & \\
\hline $\begin{array}{l}y \mid 44 \\
\end{array}$ & $\hat{o}$ & 農 & 44 & 肥. 頭: & 肥. 頭. 眩量 & + & - & - & + & - & - & & E. & & + & - & & - & A. & \\
\hline 38 & $\hat{o}$ & 缴 & 24 & 肥. & 肥. 失神 & +1 & & + & + & + & & & L.E & & $1-$ & +1 & $1+1$ & & - & \\
\hline
\end{tabular}


肢端肥大症二關 スル本邦報告例 ノ綜括的觀察 (2)

\begin{tabular}{|c|c|c|c|c|c|c|c|c|c|c|c|c|c|c|c|c|c|c|c|c|c|}
\hline \multirow{2}{*}{$\begin{array}{l}\text { 番 } \\
\text { 號 }\end{array}$} & \multirow{2}{*}{$\begin{array}{l}\text { 年 } \\
\text { 齡 }\end{array}$} & \multirow{2}{*}{ 性 } & \multirow{2}{*}{$\begin{array}{l}\text { 職 } \\
\text { 業 }\end{array}$} & \multirow{2}{*}{ 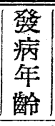 } & \multirow{2}{*}{ 初發 症 狀 } & \multirow{2}{*}{ 主訴 } & \multicolumn{5}{|c|}{ 主 } & \multicolumn{2}{|c|}{ 症 } & \multicolumn{5}{|c|}{ 获 } & \multirow{2}{*}{$\begin{array}{l}\text { わ } \\
\text { 氏 } \\
\text { 反 } \\
\text { 應 }\end{array}$} & \multirow{2}{*}{$\mid \begin{array}{l}\text { 合 } \\
\text { 併 } \\
\text { 症 }\end{array}$} & \multirow{2}{*}{$\begin{array}{l}\text { 病 } \\
\text { 型 }\end{array}$} \\
\hline & & & & & & & 尖 & 筋 & 鞍 & 頭 & 眼 & 性 & 腺 & 血 & 基 & 糖 & 植 & 精 & & & \\
\hline 31 & 21 & 9 & - & 9 & 肥. 痛. & 頭. 肥. 耳鳴. & + & & + & + & - & + & - & N.M & \pm & - & + & + & - & A. & $\begin{array}{l}\mathrm{Ah} \\
\mathrm{Pa}\end{array}$ \\
\hline 2 & 33 & $\hat{o}$ & 魚 & 27 & & & + & & + & + & + & & & & & & & & & - & $\mathrm{Ea}$ \\
\hline 33 & 52 & $\hat{o}$ & 商 & 45 & ．流涎. 筋力弱化 & 筋力減退. & + & + & + & & + & + & & - & & + & + & + & & - & Asp \\
\hline 4 & 40 & $\hat{o}$ & 夫 & 21 & 肥. 頭. 視. & 視. & + & $t$ & + & + & + & - & + & - & & - & & + & - & - & Asp \\
\hline 35 & 36 & む & - & 28 & 視. 頭. 像. & 視. & + & & + & + & + & + & + & L. & \pm & - & + & & & $\mathrm{T}$. & Asp \\
\hline 36 & 30 & $\hat{o}$ & 農 & 20 & 耳鳴. 頭. 眩暈 & 耳鳴. 眩量. 難圗 & + & & \pm & \pm & - & + & - & & \pm & + & + & - & - & - & Ea \\
\hline 37 & 36 & $\hat{o}$ & 職 & 18 & 肥. & 頭. 肥. 難㯖 & + & & + & + & + & $t$ & - & - & + & + & + & + & - & A. & $\mathrm{Ea}$ \\
\hline 38 & 34 & $\hat{\phi}$ & 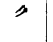 & 23 & 知. 頭. 胸內苦悶 & 知. 頭. 胸內苦悶 & + & - & + & + & + & - & & E. & & - & + & & & - & $\mathrm{Ea}$ \\
\hline 39 & 34 & 우 & 一 & 30 & $?$ & 肥. 月. 視. & + & & + & & + & + & & E. & & & & & & - & $\mathrm{Ea}$ \\
\hline 10 & 29 & 우 & - & 22 & 盵. 月. & 肥. 糖. & + & & + & - & - & + & - & $\mathrm{LN}$ & + & + & + & - & - & D. & Asp \\
\hline 11. & 35 & 우 & - & 30 & $?$ & 糖. 月. 知. & + & & + & & & + & + & & & + & + & & & D. & Asp \\
\hline 12 & 37 & $\hat{o}$ & & 29 & ? & 四肢運動障碍. & + & + & + & & & & + & & & + & + & & & D. & Asp \\
\hline 13 & 60 & $\hat{o}$ & 職 & 59 & 關節痛. & 痛. & + & & + & & - & & & | & & - & + & & & - & Asp \\
\hline 4 & 33 & 우 & - & 32 & 痛. 像. & 、陰部搔痒症. & + & & + & + & + & + & - & ANE & & + & + & & + & D. & Asp \\
\hline 5 & & $\hat{o}$ & & 23 & 肥. 頭. & 肥. 倊. & + & + & + & & + & + & & E. & & - & + & & - & - & Asp \\
\hline 6 & 51 & $\hat{o}$ & & 20 & 肥. & 肥. 痛. & + & & + & + & & + & & & & + & & & & C. & Asp \\
\hline 17 & 31 & $\hat{o}$ & 官 & 29 & 肥. 頭. 糖. & 糖尿病性昏睡. & + & & + & + & & & + & $\mathrm{LM}$ & & + & & & & D. & Asp \\
\hline 8 & 44 & $\hat{o}$ & 商 & 19 & 肥. & & + & - & + & - & - & - & & & & - & & & & - & $\mathrm{Ah}$ \\
\hline 19 & 27 & $\hat{\delta}$ & & 14 & 肥. 發汗. & 肥. 發汗. & + & & + & - & - & - & - & L. & \pm & + & + & - & & - & $\mathrm{Ea}$ \\
\hline 50 & 54 & $\hat{o}$ & 農 & 26 & 盵. & 隐. 下肢重感. & + & - & + & - & - & - & & & & + & - & & - & D. & $\mathbf{E a}$ \\
\hline 51 & 35 & 우 & - & 30 & 知. & 月. 肥. & + & & + & - & + & + & - & - & & - & + & + & - & - & Asp \\
\hline 52 & 28 & $\hat{o}$ & 商 & 26 & 肥. 痛. & 肥. 僚. 皮膚解壁 & + & & + & - & + & + & & & & & & & + & C. & $\mathrm{Ea}$ \\
\hline 33 & 48 & $\hat{o}$ & 農 & 18 & 肥. & 視. 知. 糖. & + & - & + & + & + & - & & L. & & + & + & & $1-$ & D. & Asp \\
\hline 54 & 25 & $\hat{\delta}$ & 商 & 17 & 肥. 倦. 糖. & 頭. 糖. 筋力弱化 & $t$ & + & + & + & - & + & - & ME & - & + & + & + & + & D. & $\begin{array}{l}\text { Ah. } \\
\mathrm{Pa}\end{array}$ \\
\hline 55 & 27 & $\hat{o}$ & & 21 & 肥. & 神經衰弱. & + & & + & & + & & & & & & & + & & c. & $\mathrm{Ea}$ \\
\hline 56 & 29 & $\hat{o}$ & 工 & 15 & & 肥. 結核症狀. & + & & & & & & & N. & & - & & & - & A. & $\mathrm{Ea}$ \\
\hline 57 & 54 & $\hat{o}$ & 農 & 25 & 肥. 知. & 倦. 下肢脫力感 & + & & + & & - & - & - & - & \pm & + & + & - & - & D. & Asp \\
\hline 58 & 50 & $\hat{o}$ & & 40 & 肥. 痛. & 僚. 口渴. & + & & + & + & + & - & - & - & & + & - & + & - & D. & Asp \\
\hline 9 & 42 & 우 & - & 38 & 月. & 糖. & + & & + & - & - & + & - & E. & + & + & & & - & D. & Asp \\
\hline 0 & 58 & $\hat{o}$ & 商 & 55 & 肥. & 肥. 知. 浮腫. & + & + & + & - & - & - & - & $\mathrm{EM}$ & \pm & + & + & + & - & $\mathrm{T}$. & Asp \\
\hline & & & & & & 6) & & & 91 & 76 & 65 & 67 & 65 & 71 & 65 & 54 & 89 & 81 & 14 & & \\
\hline
\end{tabular}

\begin{tabular}{|c|c|c|c|}
\hline [肥] & 肢端肥大 & [鞍] & 土耳古鞍ノ變化 \\
\hline [痛] & 疼痛 & 〔頭] & 頭痛 \\
\hline [頭] & 頭痛 & 〔眼〕 & 眼症狀(本症特有) \\
\hline [悓］ & 視力障碍 & [性] & 性殖能，變化 \\
\hline [糖] & 糖尿病症狀 & 〔腺〕 & 生殖腺以外內分泌腺變化 \\
\hline [月] & 月經異常 & 〔血] & 血液像 \\
\hline [㑽] & 全身僚意 & [基] & 基礎代謝 \\
\hline [知] & 知覺障碍 & 〔糖〕 & 糖代謝異常 \\
\hline [尖] & 尖端肥大 & 〔植〕 & 植物神絁系症爿 \\
\hline [筋] & 筋力減退 & 〔精〕 & 精神症狀 \\
\hline
\end{tabular}

(2) 職 職人(職業欄) Ea. Einfache Akromegalie

（3）報告者右下ノ數字 Asp. Akromegalie mit 八協同協告者ノ人 數 7 示 $ᄌ$

Splanchynomegalie

(4) 外國語，略字=就 Sa. Schwangerschaftakromegalie テ Pa. Pubertätsakromegalie E. Eosinophilíe D. Diabetes

L. Lymphocytose A. Andere Krankheiten M. Monocytose C. Cutis verticis gyrata N. Neutrophilie T. Tumor A. Anaemie E. Exostosen 